INTERLEUKIN-5 (IL-5) is a key mediator of eosinophilic inflammation. The biological role of this cytokine in an allergic airway inflammatory response has been widely demonstrated in guinea pigs, yet the interaction of guinea pig IL-5 (gpIL-5) with its receptor has not been studied. Experiments were performed to quantitate the interaction of gp IL-5 with gp IL-5r and to compare this affinity with that of hIL-5 and $\mathrm{m} \mathrm{IL}-5$ and their cognate receptors. The cross-species affinity and agon is tefficacy were evaluated to see if gpIL$5 \mathrm{r}$ had a restricted species reactivity (as is the case with mIL-5r) or did not distinguish between IL-5 or thologs (similar to h IL-5r). gpIL-5 was cloned using m RNA isolated from cells obtained by bronchoalveolar lavage. Recombinant gpIL-5 was expressed in T.ni in sect cells and purified from spent media. Binding assays were performed using insect cells expressing h IL- 5 r $\alpha \beta$ or gpIL- 5 r $\alpha \beta 1$ as previously described (Cytokine, 12:858-866, 2000) or using B13 cells which express mIL-5r. The agonist potency and efficacy properties of each IL-5 ortholog were evaluated by quantitating the proliferative response of hum an TF-1 cells and murine B13 cells. gpIL-5 bound with high affinity to recombinant gpIL-5 $r$ as demonstrated by displacing $\left[{ }^{125} \mathrm{I}\right] \mathrm{h}$ IL-5 $\left(K_{\mathrm{i}}=160 \mathrm{pM}\right)$. gp IL-5 also bound to hIL-5r with high affinity $\left(K_{\mathrm{i}}=750 \mathrm{pM}\right)$. hIL-5 and mIL-5 showed similar, high-affinity binding profiles to both gpIL-5r and h IL-5r. In con trast, gpIL-5 and h IL5 did not bind to the mIL-5r as demonstrated by an inability to displace $\left[{ }^{125} \mathrm{I}\right] \mathrm{m} \mathrm{IL}-5$, even at 1000 -fold molar excess. These differences in affinity for IL-5r or thologs correlated with bioassay results: human TF1 cells showed roughly comparable proliferative responses to guinea pig, human and murine IL-5 whereas murine B13 cells showed a strong preference for murine over guine a pig and human IL-5 (EC 50 $=1.9,2200$ and $720 \mathrm{pM}$, respectively). Recombinant gpIL-5 binds to the gpIL-5r with high affinity, similar to that seen with the human ligand-receptor pair. gpIL-5r and hIL-5r do not distinguish between the three IL-5 orthologs whereas $m$ IL $-5 r$ has restricted specificity for its cognate ligand.

Key words: Eosinophil, Interleukin-5, Asthma, Airway inflammation

\section{Expression and in vitro properties of guinea pig IL-5: Comparison to human and murine orthologs}

\author{
Clay W Scott ${ }^{\mathrm{CA}}$, Carol Budzilowicz, \\ Stephen J. Hubbs, Mark Stein, \\ Cindy Sobotka-Briner and Deidre E. Wilkins
}

AstraZeneca Pharmaceuticals, CNS Discovery Research, LW208, 1800 Concord Pike, Wilmington, DE 19810, USA

\footnotetext{
${ }^{\mathrm{CA}}$ Corresponding Author

Tel: $+1302-886-3177$

Fax: + 1302-886-4803

E-mail: Clay.Scott@AstraZeneca.com
}

\section{Introduction}

Activated eosinophils can produce a wide array of pro-inflammatory mediators and bronchoconstricting agents (reviewed in refs ${ }^{1,2}$ ). The increased numbers of eosinophils seen in human allergic airways ${ }^{3,4}$ and the elevated levels of eosinophil products measured in bronchoalveolar lavage (BAL) from such patients, support the hypothesis that eosinophilic inflammation is an important pathogenic component of chronic asthma. IL-5 is important for eosinophil development, mobilization from bone marrow, and activation in the allergic airway. Characterization of this cytokine and an understanding of its role has led to various therapeutic approaches to block its production and or actions (see refs ${ }^{6-8}$ for reviews).

Guinea pigs have proven a valuable species for simulating certain aspects of airway inflammation. For example, both allergen and IL-5 induced release of eosinophils from guinea pig bone marrow and their accumulation in airways have been demonstrated. ${ }^{9-11}$ Furthermore, both in vivo and in vitro studies are commonly performed with guinea pigs to evaluate therapeutic modalities aimed at reducing the allergic response in humans. Although numerous studies have described the molecular characteristics 
of human and murine IL-5 and their interaction with cognate receptors, ${ }^{12-16}$ little is known about the guinea pig ligand/receptor system. Guinea pig IL-5 (gpIL-5) has been cloned, expressed and shown to induce airway eosinophilia in guinea pigs when given by tracheal injection. ${ }^{1,17}$ We recently reported the cloning and expression of guinea pig IL-5 receptor $\alpha$ subunit and multiple $\beta$ subunits. ${ }^{18}$ We also reconstituted a high affinity gpIL- $5 \mathrm{r} \alpha \beta_{1}$ complex using hIL-5 as ligand. In this report, we extend these studies to show the high affinity interaction of guinea pig IL-5 with its recombinant receptor. We also demonstrate its cross-species affinity and agonist activity with the human and murine IL-5r and compare these results with those generated using the human and murine orthologs.

\section{Methods}

\section{Materials}

Murine IL-5 was purchased from R\&D Systems (MN). Dibutyl phthalate, phthalic acid dinonyl ester, and polyvinylpyrrolidone were purchased from Sigma (MO). Excell 400 media and SF900II media were purchased from JRH Biosciences (KS) and GIBCO-BRL (MD), respectively. TF-1 cells were purchased from ATCC (MD). B13 cells were kindly provided by Dr Dilniya Fattah (GlaxoWelcome R\&D). $\left[{ }^{125}\right.$ I]hIL-5, $\left[{ }^{125} \mathrm{I}\right] \mathrm{mIL}-5$ and [methyl-H]thymidine were purchased from NEN (MA).

\section{Cell culture}

TF-1 cells were maintained in RPMI-1640 medium supplemented with $10 \%$ fetal calf serum, $2 \mathrm{mM}$ L-glutamine, $10 \mathrm{U} / \mathrm{ml}$ penicillin and $10 \mu \mathrm{g} / \mathrm{ml}$ streptomycin. A subclone (IL-5/TF-1) displaying a greater proliferative response to human IL-5 was selected following continuous culture in the presence of human IL-5. Optimal growth conditions were maintained by splitting the cultures every 3-4 days with medium containing $5 \mathrm{ng} / \mathrm{ml} \mathrm{IL-5.} \mathrm{B13} \mathrm{cells} \mathrm{were}$ maintained in RPMI-1640 with 10\% FBS containing $5 \mathrm{ng} / \mathrm{ml}$ murine IL-5.

\section{Cloning guinea pig IL-5 cDNA}

Guinea pigs were sensitized by i.p. injection of $5 \mathrm{mg}$ ovalbumin in saline on day 1 and then $10 \mathrm{mg}$ ovalbumin on day 3 . On day 14 the animals were challenged with aerosolized ovalbumin $(1 \mathrm{mg} / \mathrm{ml}$ in saline; 60-90 s) and $24 \mathrm{~h}$ later BAL was performed. mRNA was prepared from cells present in the BAL fluid. Adapter-ligated double stranded cDNA was synthesized from mRNA using a Marathon cDNA Amplification kit (Clontech Laboratories, Inc, CA).
Guinea pig IL-5 was cloned using nested PCR with the following primers:

$$
\begin{aligned}
& \text { Primer \#1 was: } \\
& \text { 5'-CTCCGTCCAAAGGTAAAGCTGCACC-3' }
\end{aligned}
$$

Primer \#2 was:

5'-CCGGAATTCGGATCCTTGTAGCCATGAGGGTGCTTCTGC-3'.

\section{Primer \#3 was: \\ 5'-CGCGAAGCTTCCCAAAATCTCTGGATACAAT- CAGCC-3'. \\ Primer \#4 was: \\ 5'-CCACATGGTACCCCATTAAAACATGTAC-3.}

Primer \#2 incorporates EcoR1 and BamH1 sites and Primer \#3 incorporates a HindIII site for subcloning into the pFASTBac1 vector sites. First round PCR amplification was done using $5 \mu 1$ of a 1:100 dilution of the product of a $1 \mu \mathrm{g}$ Marathon cDNA reaction as template. Primers \#1 and \#4 and Clontech's Advantage Polymerase mix were used in the first round PCR amplification which consisted of 30 cycles of $1.5 \mathrm{~min}$ at $94^{\circ} \mathrm{C}, 2 \mathrm{~min}$ at $55^{\circ} \mathrm{C}$ and $2 \mathrm{~min}$ at $68^{\circ} \mathrm{C}$. One microliter of the 1st round PCR product was used as template in a second round reaction which used Primers \#2 and \#3. Conditions were the same as those described for first round PCR. The product of the second round PCR reaction was purified from an agarose gel using Qiagen's Qiaquick gel purification system and ligated into Novagen's pT7Blue T-Vector. A clone matching the published sequence (Genbank Accession \#U34588) was identified and used to prepare expression vectors.

\section{Expressing recombinant proteins using baculovirus expression system}

The gpIL-5 cDNA was subcloned into the pFastBac-1 vector (GIBCO-BRL) downstream of the polyhedrin promoter. Recombinant baculovirus was obtained according to the Bac-to-Bac ${ }^{\mathrm{TM}}$ Baculovirus Expression System (Life Technologies, MD) protocols. High titer viral stocks were prepared in Sf9 cells using SF900II media. Optimal protein production was achieved using T.ni cells $\left(3 \times 10^{6}\right.$ cells $\left./ \mathrm{ml}\right)$ in Excell 400 media with high titer virus at a multiplicity of infection of 5-10. Supernatants were harvested $72 \mathrm{~h}$ after infection and stored at $4^{\circ} \mathrm{C}$.

Recombinant gpIL-5r $\alpha \beta_{1}$ and hIL-5r $\alpha \beta$ complexes were produced in Sf9 cells as previously described. ${ }^{18}$ Recombinant hIL-5 was expressed in Sf9 cells using procedures described by Brown et al. ${ }^{19}$ 


\section{IL-5 purification}

hIL-5 was purified by a combination of Q-Sepaharose, hydoxylapatite and phenyl Sepaharose column chromatography as described by Johanson $e t$ $a l^{20}$ gpIL-5 was purified in a single step by negative selection ion exchange chromatography on Q-Sepharose $\mathrm{ff}^{19}$ equilibrated with $10 \mathrm{mM}$ Tris-HCl, $\mathrm{pH}$ 8. The gpIL-5 eluted in the exclusion volume while the remaining proteins were bound to the column. Contaminating lipids were precipitated by a 1:1 addition of $2 \mathrm{M}\left(\mathrm{NH}_{4}\right)_{2} \mathrm{SO}_{4}$ and then separated by centrifugation. The gpIL-5 preparation was then dialyzed against $50 \mathrm{mM} \mathrm{NaHPO} 4,150 \mathrm{mM} \mathrm{NaCl}, \mathrm{pH}$ 7.0 to remove the $\left(\mathrm{NH}_{4}\right)_{2} \mathrm{SO}_{4}$.

\section{Binding assay}

Insect cells expressing either hIL-5r $\alpha \beta$ or gpIL$5 \mathrm{r} \alpha \beta_{1}$ were processed for binding assays as previously described. ${ }^{18}$ Plasma membrane preparations $\left(5 \mu \mathrm{g}\right.$ aliquots) were incubated with $50 \mathrm{pM}\left[{ }^{125} \mathrm{I}\right] \mathrm{hIL}-$ 5 in assay buffer consisting of $25 \mathrm{mM}$ Tris, $\mathrm{pH} 7.4$ and $150 \mathrm{mM} \mathrm{NaCl}$. Some samples also received various concentrations of unlabeled human, guinea pig, or murine IL-5. The samples were incubated at $23^{\circ} \mathrm{C}$ for $1 \mathrm{~h}$ and then vacuum filtered through 96-well GF/C filter plates (Packard, Meriden, CT) presoaked in $0.6 \%$ polyvinylpyrrolidone, $0.1 \%$ Tween-20. The filters were washed with $6 \times 1 \mathrm{ml}$ aliquots of wash buffer (10 mM Tris, pH 7.4, $100 \mathrm{mM} \mathrm{NaCl}, 0.02 \% \mathrm{BSA}$ ) and dried. Scintillation fluid was added and the amount of bound ligand measured using the TopCount Scintillation Counter (Packard). Specific binding was determined by subtracting the amount of binding observed in the presence of a 100-fold excess of unlabeled hIL-5. The membrane preparations containing hIL-5r $\alpha \beta$ and gpIL-5 $\mathrm{r} \alpha \beta_{1}$ showed greater than $90 \%$ specific binding when incubated with $50 \mathrm{pM}\left[{ }^{125} \mathrm{I}\right] \mathrm{hIL}-5$. Equilibrium binding constants $\left(K_{\mathrm{d}}\right.$ and $\left.K_{\mathrm{i}}\right)$ and receptor densities $\left(B_{\max }\right)$ were determined using GraphPad (CA) InPlot software.

B13 cells were used to measure binding of various IL-5 orthologs to the mIL-5r. $1 \times 10^{6}$ cells were incubated with $50 \mathrm{pM}\left[{ }^{125} \mathrm{I}\right] \mathrm{mIL}-5$ in RPMI-1640 media, $10 \%$ FBS, and $0.02 \%$ sodium azide. Some samples also received various concentrations of unlabeled murine, human or guinea pig IL-5. The samples were incubated at $23^{\circ} \mathrm{C}$ for $1 \mathrm{~h}$ and then overlaid onto $0.8 \mathrm{ml}$ of a phthalate oil mixture $(66 \%$ dibutyl phthalate, $34 \%$ phthalic acid dinonyl ester) in $1.5 \mathrm{ml}$ microcentrifuge tubes. The tubes were centrifuged at $13,000 \times g$ for $3 \mathrm{~min}$, snap frozen in a dry ice/methanol bath and cut just above the cell pellet. Cell-associated radioactivity was determined using a gamma counter (LKB Pharmacia, NJ).

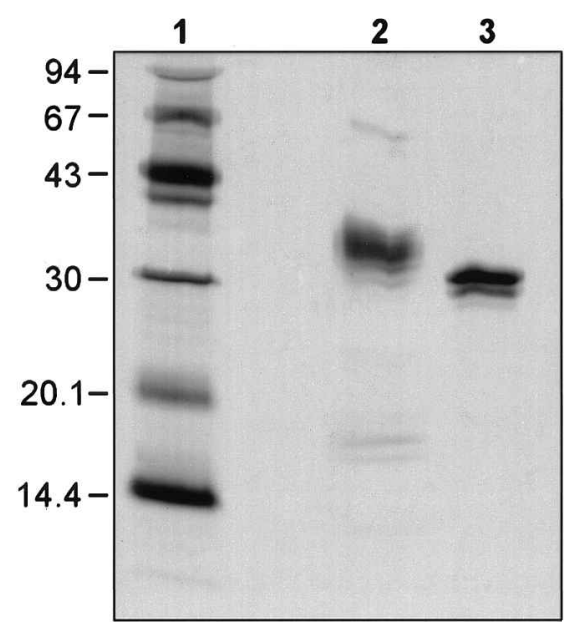

FIG. 1. SDS-PAGE analysis of gplL-5 and hIL-5. The recombinant proteins were purified as described in Methods. Aliquots of gplL-5 (0.05 $\mu$ g; lane 2$)$ or hIL-5 $(0.1 \mu \mathrm{g}$; lane 3$)$ were treated with SDS sample buffer in the absence of reducing agent and then run on a 20\% SDS PhastGel (PhastSystem; Amersham Pharmacia Biotech). The gel was silver stained. The bands in lane 1 represent protein standards, with corresponding Mr noted in the margin.

\section{Proliferation assay}

TF-1 and B13 cells were washed in PBS then resuspended in growth media in the absence of serum. After $4 \mathrm{~h}$ of serum starvation the cells were seeded at $1.25 \times 10^{4}$ cells/well in a 96-well microtitre plate with various concentrations of cytokine or media alone. Proliferation was measured by pulsing cultures during the last $6 \mathrm{~h}$ of a $72 \mathrm{~h}$ culture period with $0.5 \mu \mathrm{Ci}$ of [methyl- ${ }^{3}-\mathrm{H}$ ]-thymidine per well. Samples were harvested on a 96-well UniFilter TM-96 GF/C filter plate (Packard, Meriden, CT). MicroScint20 scintillation fluid (Packard) was added and incorporated $\left[{ }^{3} \mathrm{H}\right]$-thymidine measured using the TopCount Microplate Scintillation Counter system (Packard).

\section{Results}

\section{Cloning and expression of guinea pig IL-5}

Mansour et al. ${ }^{11}$ had previously reported the cloning of gpIL-5 from cells isolated from guinea pig spleen. We utilized a similar strategy, albeit using cells isolated by bronchoalveolar lavage (BAL) of ovalbumin-challenged animals. This method is known to yield an enriched preparation of eosinophils and Th2 cells, both of which produce IL-5. ${ }^{21-23} \mathrm{~A}$ cDNA clone was obtained which had a predicted amino acid sequence identical to that published by Mansour et al. ${ }^{11} \mathrm{~A}$ recombinant baculovirus construct was generated containing this clone and was used to express recombinant protein in $\mathrm{T}$. ni insect cells.

Recombinant gpIL-5 was purified from the T.ni cell spent media using essentially a single step ion exchange chromatography procedure described by 


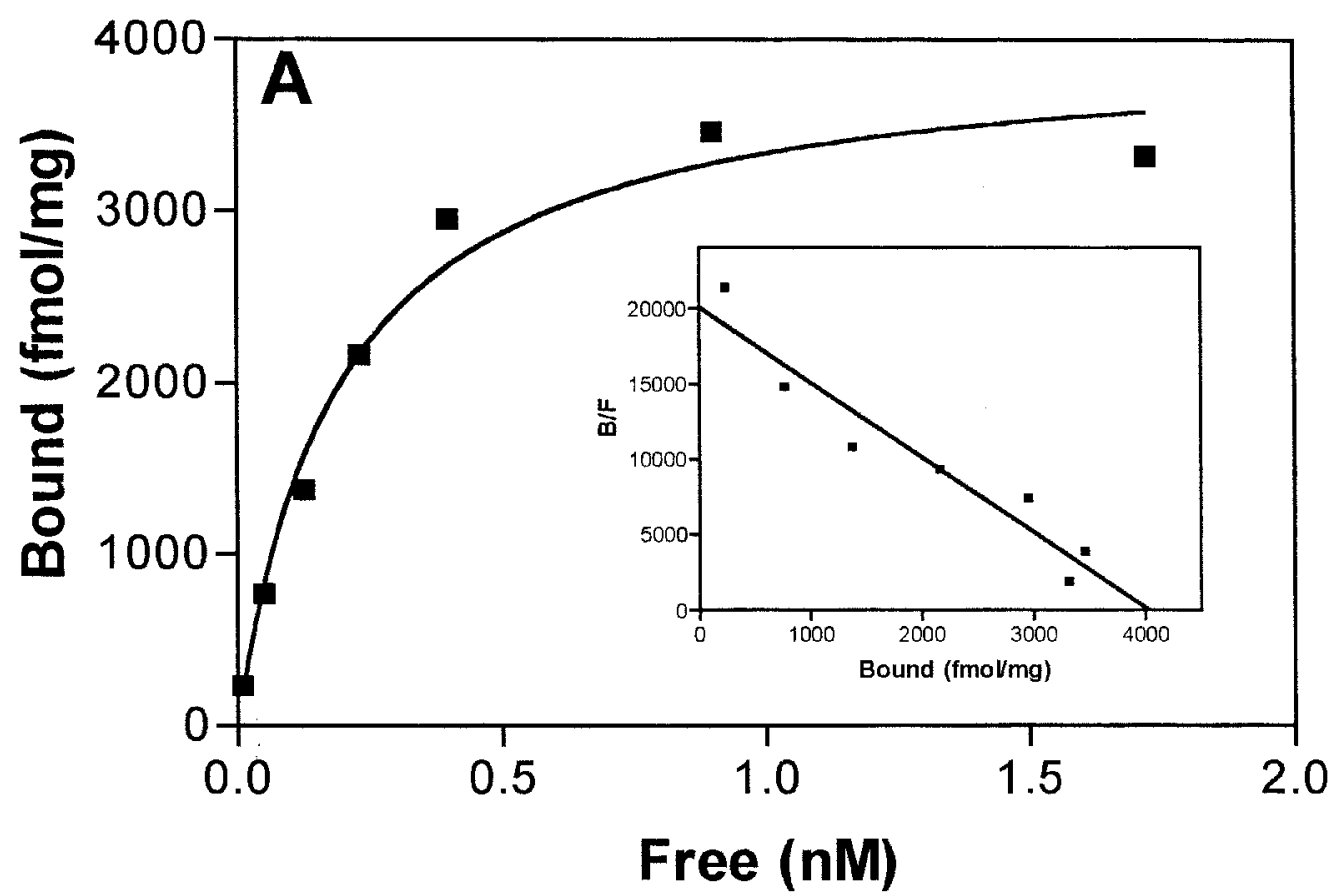

FIG. 2. Saturation analysis of $\left[{ }^{125} \mathrm{I}\right] \mathrm{hIL}-5$ binding to Sf9 membranes expressing hIL-5r $\alpha \beta$. Plasma membranes from Sf9 cells infected with baculovirus containing hIL-5r $\alpha \beta$ were incubated with $30 \mathrm{pM}-5 \mathrm{nM}$ [ ${ }^{125}$ I] $\mathrm{hlL}-5$ under standard binding conditions. Data were analyzed as discussed in Methods and linearized according to the method of Scatchard (inset). Data represent the mean of triplicate determinations from a typical experiment.

Brown et al. ${ }^{19}$ As shown in Fig. 1, the purified protein migrates at the expected $\mathrm{Mr}$ on SDS-PAGE under nonreducing conditions, and is consistent with the known homodimeric form of the mature, biologically active protein. gpIL-5 migrates as a slightly higher $\mathrm{Mr}$ protein compared to human IL-5, presumably due to an additional glycosylation site (N59) plus a slightly larger molecular mass of the peptide sequence (13.36 vs $13.15 \mathrm{kDa})$. In the presence of reducing agent, both IL-5 preparations run at $15-18 \mathrm{kDa}$, which is consistent with the mature protein being comprised of disulfide-linked monomers (data not shown). The set of 2-3 bands seen with both preparations have been observed by others expressing guinea pig and human IL-5 in insect cells and represents differentially glycosylated forms of IL-5. ${ }^{11,19,24}$

\section{Binding to human and guinea pig IL-5r}

The IL-5r is a heteromeric complex comprising an $\alpha$ and $\beta$ subunit. The human IL-5r $\alpha$ and $\beta$ subunits were co-expressed in Sf9 cells, and plasma membrane preparations derived from these cells were used to reconstitute high affinity binding with $\left[{ }^{125} \mathrm{I}\right] \mathrm{hIL}-5$ (Fig. 2). ${ }^{18}$ Analysis of equilibrium binding data indicates a single population of saturable binding sites with a $K_{\mathrm{d}}=220 \mathrm{pM}$. This affinity is consistent with that shown for the binding of hIL-5 to human eosinophils. ${ }^{25-27} \mathrm{~A}$ similar high affinity binding site is observed with $\left[{ }^{125}\right.$ I]hIL-5 and membrane preparations expressing
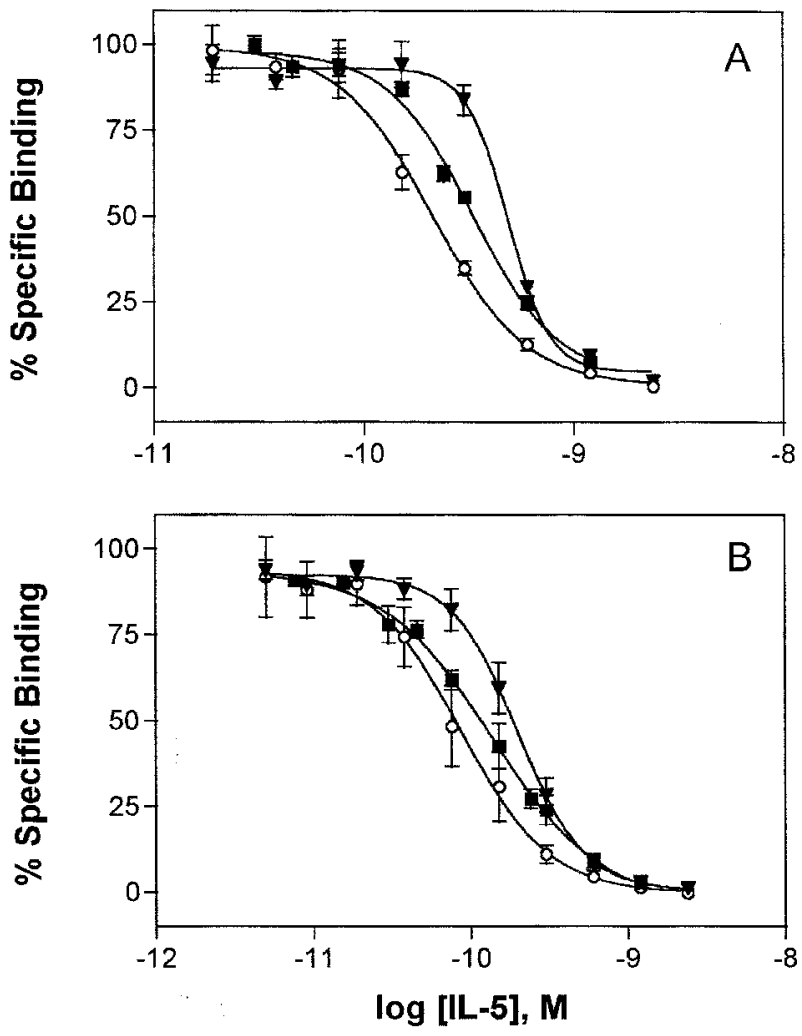

FIG. 3. Inhibition of $\left[{ }^{125} \mathrm{I}\right] \mathrm{hlL}-5$ binding to human or guinea pig IL-5r by IL- 5 orthologs. Membranes containing hIL-5r $\alpha \beta$ (A) or gplL-5r $\alpha \beta_{1}$ (B) were incubated with $50 \mathrm{pM}\left[{ }^{125} \mathrm{I}\right] \mathrm{hIL}-5$ in the presence of various concentrations of gplL-5 $(\nabla)$, hIL-5 (ם), or mIL-5 $(\bigcirc)$. Data are expressed as percent of control binding and represent the mean \pm SEM from three experiments performed in triplicate. 


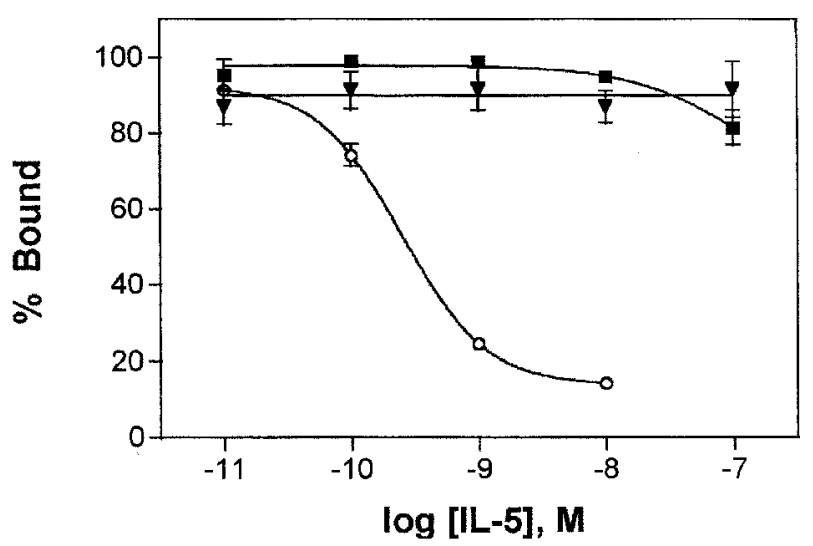

FIG. 4. Inhibition of $\left[{ }^{125} \mathrm{I}\right] \mathrm{mlL}-5$ binding to $\mathrm{B} 13$ cells by IL-5 orthologs. Cells were incubated with $50 \mathrm{pM}\left[{ }^{125} \mathrm{I}\right] \mathrm{mIL}-5$ in the presence of various concentrations of gplL- $5(\nabla)$, hIL-5 ( $\mathbf{\square})$, or $\mathrm{mIL}-5(\bigcirc)$. After $60 \mathrm{~min}$, cells were centrifuged through an oil layer to separate bound from free ligand and the cell pellet processed as described in Methods. Data are expressed as percent of control binding and represent the mean \pm SEM from three experiments performed in triplicate.

guinea pig IL-5r $\alpha$ and $\beta_{1}$ subunits $\left(K_{\mathrm{d}}=110 \mathrm{pM}\right) .{ }^{18}$ These two preparations were used in displacement binding assays to determine whether gpIL-5 binds to gpIL-5r $\alpha \beta_{1}$ with an affinity similar to that seen with the human and murine ligand/receptor pairs and also to determine the relative affinities of guinea pig, murine and human IL-5 for the guinea pig and human IL-5 receptors.

As shown in Fig. 3a, the binding of $\left[{ }^{125} \mathrm{I}\right] \mathrm{hIL}-5$ to hIL- $5 \mathrm{r} \alpha \beta$ was blocked with an excess of unlabeled hIL-5. The affinity of hIL-5 for hIL-5r $\alpha \beta$ determined by the displacement assay $\left(K_{\mathrm{i}}=470 \mathrm{pM}\right)$ agrees with that obtained in the saturation binding experiment described in Fig. $2\left(K_{\mathrm{d}}=220 \mathrm{pM}\right)$. mIL-5 displaced the binding of $\left[{ }^{125} \mathrm{I}\right] \mathrm{hIL}-5$ to the hIL-5r $\alpha \beta$ preparation, and did so with a potency $\left(K_{\mathrm{i}}=170 \mathrm{pM}\right)$ similar to that seen with hIL-5. This is consistent with published results using human eosinophils as the source of IL-5r, indicating that human and murine IL-5 bind to the hIL5 r with similar affinity. ${ }^{27}$ Finally, gpIL-5 also bound to the hIL-5 $\mathrm{r} \alpha \beta$ with high affinity $\left(K_{\mathrm{i}}=750 \mathrm{pM}\right)$, a value that was only 2 and 4 .4-fold less potent than hIL-5 and mIL-5, respectively.

A similar set of competitive inhibition experiments was performed with plasma membranes from T.ni cells expressing gpIL-5r $\alpha \beta_{1}$ (Fig. 3b). gpIL-5 bound to it's cognate receptor with high affinity, as demonstrated by blocking the binding of $\left[{ }^{125} \mathrm{I}\right] \mathrm{hIL}-5$ with a $K_{\mathrm{i}}=160 \mathrm{pM}$. This affinity is similar to that seen with the human IL-5 ligand/receptor pair. Both murine and human IL-5 also bound to this gpIL-5r preparation with high affinity, showing $K_{\mathrm{i}}=57$ and $97 \mathrm{pM}$, respectively. Thus, all three IL-5 orthologs bind to the recombinant guinea pig and human IL-5 receptors with high affinities, and differ from each other in potencies against either receptor preparation by less
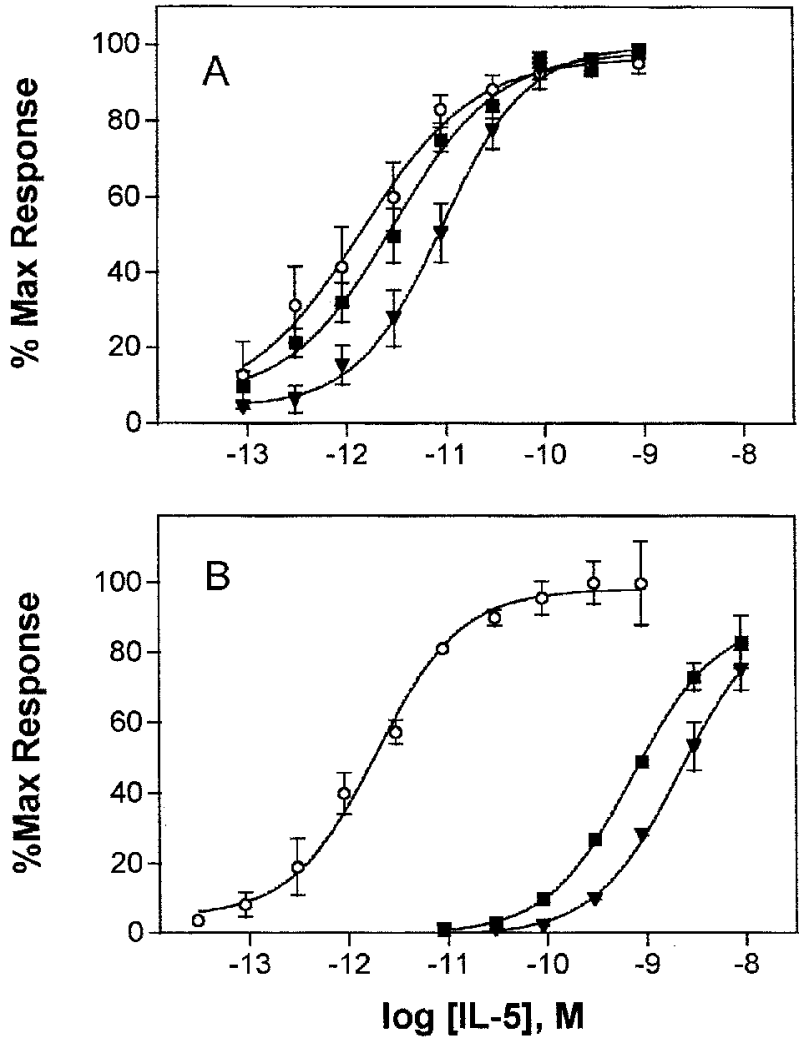

FIG. 5. Biological activity of IL-5 orthologs on human IL-5/TF1 cells and murine B13 cells. Both IL-5/TF- 1 (A) and B13 (B) cells were incubated with increasing concentrations of gplL$5(\nabla)$, hIL-5 $(\square)$, or mIL-5 $(\bigcirc)$ for $72 \mathrm{~h}$ and the proliferative response measured by incorporation of $\left[{ }^{3} \mathrm{H}\right]$ thymidine as described in Methods. Data represent the mean \pm SEM from three experiments performed in triplicate.

than 5-fold. For both preparations of receptors, these ligands demonstrated the same rank order potency with mIL-5>hIL-5>gpIL-5.

\section{Binding to murine IL-5r}

B13 cells are a murine Ly1+ pre-B cell line previously shown to express receptors for mIL-5 and to proliferate in response to this cytokine. ${ }^{28,29}$ These cells were used to determine the relative affinities of the IL5 orthologs for the murine receptor. As shown in Fig. 4 , binding of $\left[{ }^{125} \mathrm{I}\right] \mathrm{mIL}-5$ can be displaced with unlabelled mIL-5 but not hIL-5. Only at the highest concentration of hIL-5 tested was there noticeable displacement of $\left[{ }^{125} \mathrm{I}\right] \mathrm{mIL}-5$. This is consistent with previous reports indicating that mIL-5 binds to mIL-5r with a 400-5000-fold higher affinity than hIL-5. ${ }^{30,31}$ Interestingly, the results with gpIL-5 closely resembled that of hIL-5 rather than mIL-5, i.e. gpIL-5 was unable to displace $\left[{ }^{125} \mathrm{I}\right] \mathrm{mIL}-5$ from the mIL-5r. These results indicate that high affinity binding seen with mIL-5 is not shared with all other rodent IL-5 orthologs. 


\section{Biological activity of recombinant gpIL-5}

The biological activity of gpIL-5 was assessed using a subclone of human TF-1 cells, (IL-5/TF-1), previously isolated by long-term culture in hIL-5 and showing a stronger proliferative response to hIL- 5 compared to the parental line. Similar subclones have been isolated by others using the same strategy. ${ }^{32}$ As shown in Fig. $5 \mathrm{a}$, these cells proliferate in response to all three IL-5 orthologs, with gpIL-5 showing slightly less activity compared to murine and human IL-5 $\left(\mathrm{EC}_{50}=9.1\right.$ vs 1.4 and $2.9 \mathrm{pM}$, respectively). The IL-5 orthologs induce proliferation at concentrations below their $K_{\mathrm{d}}$ for the hIL-5r which indicates the presence of spare receptors on these cells. All three IL -5 orthologs produced the same maximal proliferative response with the IL5/TF-1 cells and did so with the same rank order potency observed in the binding experiments.

In contrast to the results with IL-5/TF-1 cells, there was a substantial difference in the ability of guinea pig, human and murine IL-5 to induce proliferation of B13 cells (Fig. 5b). mIL-5 was 350-1000-fold more potent than human or guinea pig IL-5. This separation in potency of the biological responses by the murine receptor is consistent with the different binding affinities for this receptor. All three IL-5 preparations had similar intrinsic activities on the mIL- 5 r, i.e. were capable of eliciting a maximal response, but their relative potencies reflected the differences in affinity for this receptor. Thus, only mIL-5 can bind and activate the mIL-5r with high affinity.

\section{Discussion}

Delineating the biological interaction of guinea pig IL5 with its receptor would prove useful for comparison to the human ligand/receptor pair, particularly for relating the molecular properties of hIL-5r antagonists to their in vivo profile in guinea pig models of allergic airway disease. Although gpIL-5 and gpIL-5r have been cloned and expressed in biologically active forms,${ }^{11}$ their interaction has not been evaluated. In this paper we describe the binding affinity of recombinant gpIL-5 to its receptor and compare its crossspecies affinity and agonist activity with that of human and murine IL-5.

As shown in Fig. 3, guinea pig IL-5 bound with high affinity to recombinant gpIL-5r $\alpha \beta_{1}$ expressed in Sf9 cells. It bound with a similar high affinity to hIL-5r $\alpha \beta$, but did not demonstrate appreciable binding to mIL$5 r$ on B13 cells. Under the conditions used in the mouse B13 cell binding assay, gpIL-5 showed no inhibition of binding at a concentration 1000-fold higher than that required for displacement with mIL5 , indicating that gpIL-5 has at least 1000-fold lower affinity for the murine receptor compared to mIL-5. Human IL-5 showed a binding profile that was remarkably similar to gpIL-5 across the three receptor preparations, namely high affinity binding to hIL-5r and gpIL-5r, but not mIL-5r. Furthermore, the affinity of gpIL-5 for its cognate receptor is similar to that observed with the human IL-5 ligand/receptor pair (Fig. 3). ${ }^{12,33}$

Recombinant gpIL-5 activated the hIL-5r on human TF-1 cells, stimulating a maximal proliferative response with a potency similar to that seen with hIL5. gpIL-5 was also a full agonist for the mIL-5r expressed on B13 cells, but was 1000-fold less potent than mIL-5. Thus, the biological potency of gpIL-5 correlated with its receptor-binding affinity. A similar correlation between receptor binding affinity and agonist potency was observed with hIL-5 and is consistent with previous reports. ${ }^{13,30}$

Both murine/human chimeric polypeptides and alanine scanning mutagenesis have been used to identify the key charged residues on hIL-5 involved in binding to the hIL-5r $\alpha$ and $\beta$ subunits. ${ }^{14,16,31,34,35}$ These studies have shown that amino acids E88, R90 and E109 are involved in interactions with the receptor $\alpha$ chain while E12 is critical for $\beta$ chain binding and receptor activation. All of these amino acids are identical for the human, murine and guinea pig IL-5 orthologs. Site directed mutagenesis studies also identified the residues on hIL-5 responsible for the very weak binding affinity to mIL-5r. ${ }^{13}$ Replacing two amino acids on hIL-5 with the murine counterparts, K84E and N108s, produced a mutant protein with a biological activity similar to mIL-5. Single mutations had biological activities in between mIL-5 and hIL-5. This indicates that both K84 and N108 are key residues on hIL-5 which prevent high affinity binding to mIL-5r. Interestingly, gpIL-5 does not bind to mIL-5r with high affinity, and like hIL-5 contains asparagine at residue 108 . However, gpIL-5 contains glutamine at position 84, not lysine like hIL-5. Therefore, high affinity binding to mIL-5r likely requires an acidic side chain (E) at residue 84 for neither a basic side chain (K) nor an amide side chain $(\mathrm{Q})$ are tolerated. The amino acid sequence of both rat and gerbil IL-5 are known, and both contain E84 and S108 like the murine ortholog. Thus, gpIL-5 appears to be an outlier within the rodent family, having an amino acid sequence at critical domains that are more similar to hIL-5 and demonstrating cross-species biological activity that mimics the human ortholog.

The data in this report indicates that guinea pig and human IL-5 are similar in their cross-species profiles: both are relatively poor agonists on the mIL-5r yet bind human and guinea pig IL-5r with high affinity. Murine IL-5 binds with high affinity to all three IL-5 receptors. These data support the use of guinea pig models to evaluate the in vivo profile of compounds designed to block the interaction of hIL-5 with its cognate receptor. The identification and optimization of such compounds remains a substantial challenge. 


\section{References}

1. Silberstein DS. Eosinophil function in health and disease. Critical Reviews in Oncology-Hematology 1995; 19:47-77.

2. Strek M, Leff AR. Eosinophils, In: Barnes PJ, Leff AR, Grunstein MM, Woolcock AJ, eds. Asthma. Philadelphia: Lippincott-Raven; 1997; 399.

3. Bousquet J, Chanez P, Lacoste JY, et al. Eosinophilic inflammation in asthma. N Engl J Med 1990; 323:1033-9.

4. Wardlaw AJ, Dunnette S, Gleich GJ, Collins JV, Kay AB. Eosinophils and mast cells in bronchoalveolar lavage in subjects with mild asthma Relationship to bronchial hyperreactivity. Am Rev Respir Dis 1988; 137:62-9.

5. Sur S, Gleich GJ, Swanson MC, Bartemes KR, Broide DH. Eosinophilic inflammation is associated with elevation of interleukin- 5 in the airways of patients with spontaneous symptomatic asthma. J Allergy \& Clin Immunol 1995; 96:661-8.

6. Hamelmann E, Gelfand EW. Role of IL-5 in the development of allergeninduced airway hyperresponsiveness. Int Archives of Allergy \& Im $m u$ nol 1999; 120:8-16.

7. Hogan SP, Foster PS. Cytokines as targets for the inhibition of eosinophilic inflammation. Pharmacol Therapeut 1997; 74:259-83.

8. Devos R, Plaetinck G, Cornelis S, Guisez Y, Van der HJ, Tavernier J Interleukin-5 and its receptor: a drug target for eosinophilia associated with chronic allergic disease. J Leukoc Biol 1995; 57:813-9.

9. Mauser PJ, Pitman A, Witt A, et a l. Inhibitory effect of theTRFK-5 anti-IL-5 antibody in a guinea pig model of asthma. Am Rev Respir Dis 1993; 148:1623-7.

10. Palframan RT, Collins PD, Severs NJ, Rothery S, Williams TJ, Rankin SM Mechanisms of acute eosinophil mobilization from the bone marrow stimulated by interleukin 5: the role of specific adhesion molecules and phosphatidylinositol 3-kinase. J Exp Med 1998; 188:1621-32.

11. Mansour M, Karmilowicz M, Hawrylik SJ, et a l. Production and characterization of guinea pig IL-5 in baculovirus-infected insect cells. $\mathrm{Am} \mathrm{J}$ Physiol 1996; 270:L1002-7.

12. Takaki S, Murata Y, Kitamura T, Miyajima A, Tominaga A, Takatsu K. Reconstitution of the functional receptors for murine and human interleukin 5. J Exp Med 1993; 177:1523-9.

13. Cornelis S, Plaetinck G, Devos R, et a . Detailed analysis of the IL-5-IL-5R alpha interaction: characterization of crucial residues on the ligand and the receptor. $E M B O J 1995 ; 14: 3395-402$.

14. Graber P, Proudfoot AE, Talabot F, et al. Identification of key charged residues of human interleukin-5 in receptor binding and cellular activation. J Biol Chem 1995; 270:15762-9.

15. Dickason RR, Huston MM, Huston DP. Delineation of IL-5 domains predicted to engage the IL-5 receptor complex. I Im munol 1996; 156:1030-7.

16. Li J, Cook R, Chaiken I. Mutants of single chain interleukin 5 show asymmetric recruitment of receptor alpha and betac subunits. $J$ Biol Chem 1996: 271:31729-34.

17. Lilly CM, Chapman RW, Sehring SJ, Mauser PJ, Egan RW, Drazen JM Effects of interleukin 5-induced pulmonary eosinophilia on airway reactivity in the guinea pig. Am J Physiol 1996: 270:L368-75.

18. Scott CW, Logsdon NJ, Wilkins DE, Norris TE, Sobotka-Briner C, Hubbs S, Graham A. Molecular cloning of the guinea pig IL-5 receptor alpha and beta subunits and reconstitution of a high affinity receptor. Cytokine 2000: 12:858-66.

19. Brown PM, Scheid MP, O'Neill GP, Tagari PC, Nicholson DW. A single-step purification of biologically active recombinant human interleukin-5 from a baculovirus expression system. Protein Expression \& Purification 1995: 6:63-71.
20. Johanson K, Appelbaum E, Doyle M, et al. Binding interactions of human interleukin 5 with its receptor alpha subunit. Large scale production, structural, and functional studies of Drosophila-expressed recombinant proteins. J Biol Chem 1995: 270:9459-71.

21. Mosmann TR, Cherwinski H, Bond MW, Giedlin MA, Coffman, RL. Two types of murine helper T cell clone. I. Definition according to profiles of lymphokine activities and secreted proteins. I Immunol 1986: 136:2348-57.

22. Dubucquoi S, Desreumaux P, Janin A, Klein O, Goldman M, Tavernier J, Capron A, Capron M. Interleukin 5 synthesis by eosinophils: association with granules and immunoglobulin-dependent secretion. $J$ Exp Med 1994: 179:703-8.

23. Kay AB, Barata L, Meng Q, Durham SR, Ying S. Eosinophils and eosinophil-associated cytokines in allergic inflammation. Int Archives of Allergy \& Im m unol 1997: 113:196-9.

24. Ingley E, Cutler RL, Fung MC, Sanderson CJ, Young IG. Production and purification of recombinant human interleukin-5 from yeast and baculovirus expression systems. Eur J Biochem 1991: 196:623-9.

25. Lopez AF, Vadas MA, Woodcock JM, et al. Interleukin-5, interleukin-3, and granulocyte-macrophage colony-stimulating factor cross-compete for binding to cell surface receptors on human eosinophils. J Biol Chem 1991: 266:24741-7

26. Chihara J, Plumas J, Gruart V, Tavernier J, Prin L, Capron A, Capron M. Characterization of a receptor for interleukin 5 on human eosinophils: variable expression and induction by granulocyte/macrophage colonystimulating factor. J Exp Med 1990: 172:1347-51.

27. Migita M, Yamaguchi N, Mita S, et al. Characterization of the human IL-5 receptors on eosinophils. Cell Im mu nol 1991: 133:484-97.

28. Rolink A, Melchers F, Palacios R. Monoclonal antibodies reactive with the mouse interleukin 5 receptor. J Exp Med 1989: 169:1693-701.

29. Barry SC, McKenzie AN, Strath M, Sanderson CJ. Analysis of interleukin 5 receptors on murine eosinophils: a comparison with receptors on B13 cells. Cytokine 1991: 3:339-44.

30. Tsuruoka N, Funakoshi K, Kodama S, Tsujimoto M. Interaction of interleukin-5 with its receptors on murine leukemic BCL1 cells and its implication in biological activity. Cell Im munol 1990: 125:354-62.

31. McKenzie AN, Barry SC, StrathM, Sanderson CJ. Structure-function analysis of interleukin-5 utilizing mouse/human chimeric molecules EMBO J 1991: 10:1193-9.

32. Yen JJ, Hsieh YC, Yen CL, Chang CC, Lin S, Yang-Yen HF Restoring the apoptosis suppression response to IL-5 confers on erythroleukemic cells a phenotype of IL-5-dependent growth. J Immunol 1995 154:2144-52.

33. Ingley E, Young IG. Characterization of a receptor for interleukin-5 on human eosinophils and the myeloid leukemia line HL-60. Blood 1991: 78:339-44.

34. Tavernier J, Tuypens T, Verhee A, Plaetinck G, Devos R, Van der HJ, Guisez $\mathrm{Y}$, Oefner C. Identification of receptor-binding domains on human interleukin 5 and design of an interleukin 5-derived receptor antagonist. Proc Natl Acad Sci USA 1995: 92:5194-8.

35. Morton T, Li J, Cook R, Chaiken I. Mutagenesis in the C-terminal region of human interleukin 5 reveals a central patch for receptor alpha chain recognition. Proc Natl Acad Sci USA 1995; 92:10879-83.

\section{Received 20 July 2000;} accepted after revision 29 August 2000 


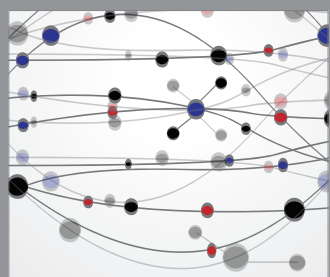

The Scientific World Journal
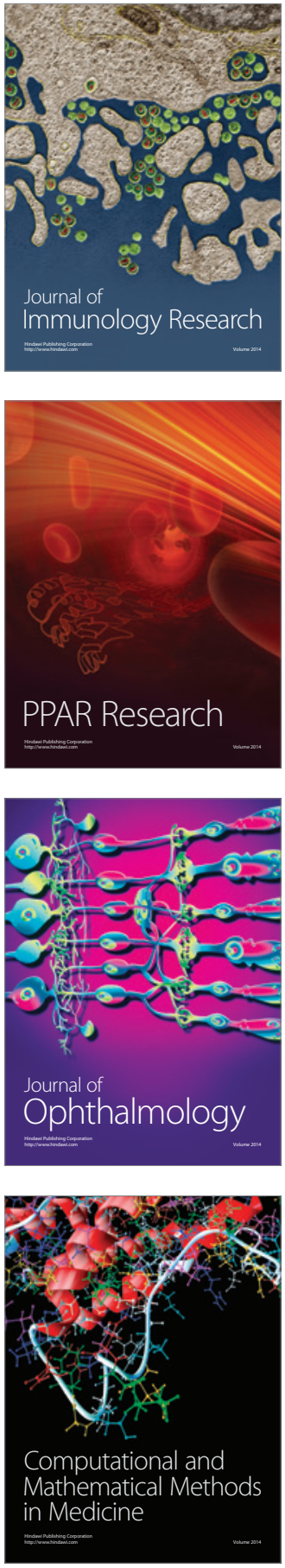

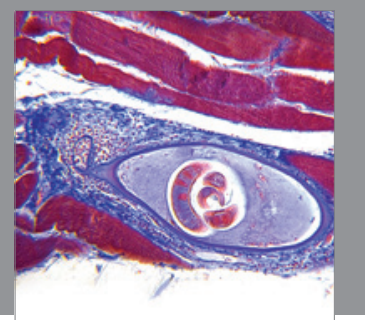

Gastroenterology

Research and Practice
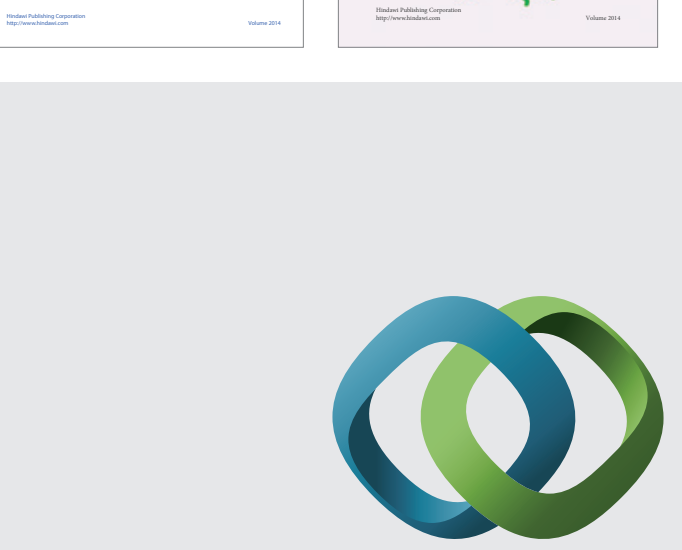

\section{Hindawi}

Submit your manuscripts at

http://www.hindawi.com
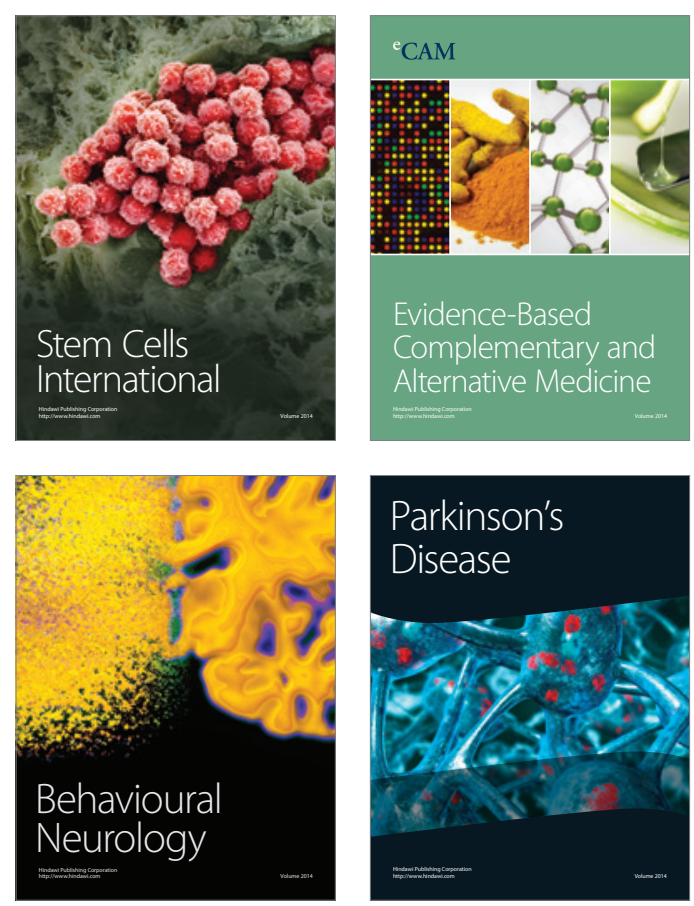

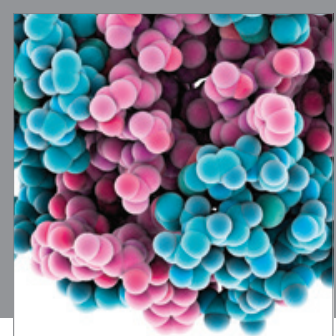

Journal of
Diabetes Research

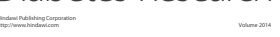

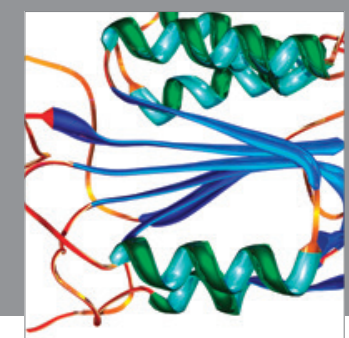

Disease Markers
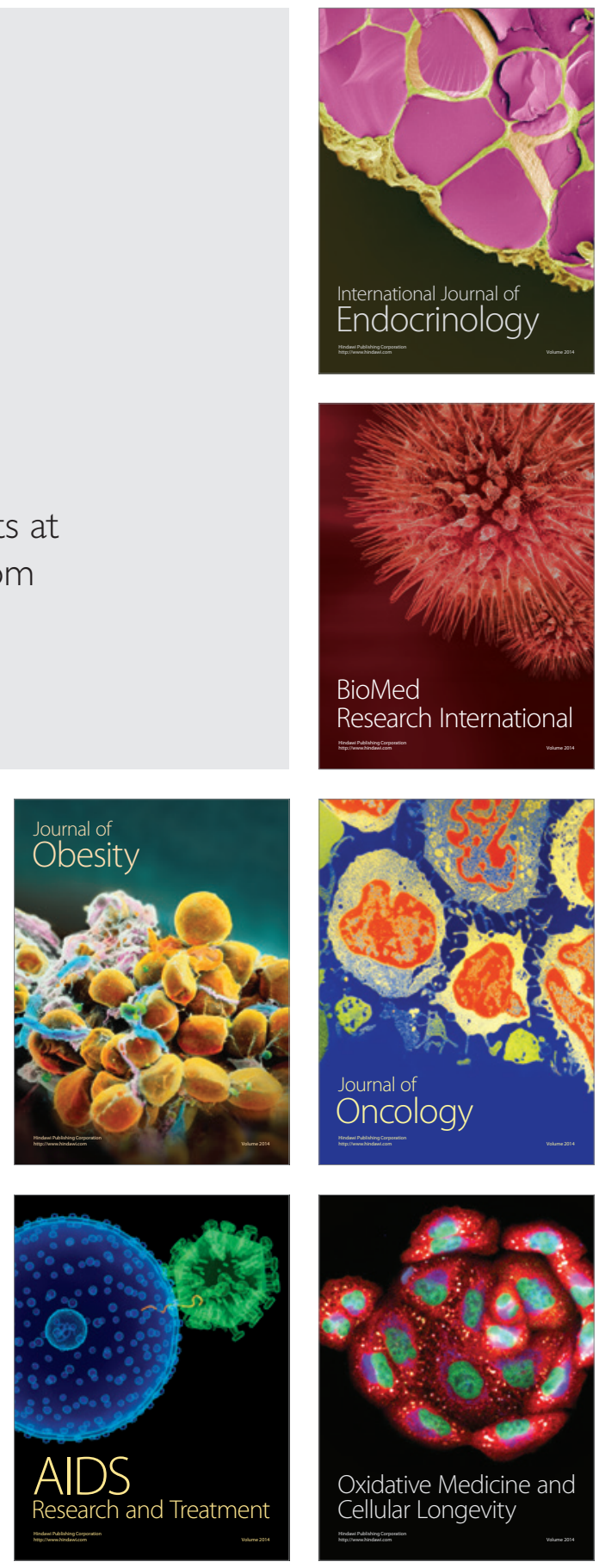